Original Contribution

\title{
THE RATIO BETWEEN THE LENGTH OF UPPER AND DOWN PARTS OF THE BODY IN THE CROSS-SECTION OF THE EQUAL TORQUES APPEARS AS AN ANATOMICAL CONSTANT
}

\author{
A. Atanasov*, N. Pirovski
}

Faculty of Medicine, Trakia University, Stara Zagora, Bulgaria,

\begin{abstract}
The bed scales determine the section, in which the torques of the upper and the down body parts are balanced. In this section the length and mass of the upper and down parts of the body were measured. Aim of the study: To investigate the ratio between the length of the upper and down part of the body in the cross-section of the equal torques of the upper and the down bodily parts. Results: 62 people between the ages of 18 and 28 were examined. The ratio $\mathrm{H}_{\text {up }} / \mathrm{H}_{\mathrm{down}}$ in the cross-section of the equal torques of the upper and down bodily parts don't depend from body height $\mathrm{H}$ and is equals to: $\mathrm{H}_{\mathrm{up}} / \mathrm{H}_{\text {down }}=0.791 \mathrm{H}$ (i.e. $\mathrm{H}_{\text {up }}$ $/ \mathrm{H}_{\text {down }} \sim 0.8 \mathrm{H}$ ). Conclusions: The ratio between the length of upper and down parts of the body in the crosssection of the equal torques of upper and lower bodily parts appears nearly an anatomical constant.
\end{abstract}

Key words: body, mass center, height, BMI, torques.

\section{INTRODUCTION}

In the previous study Atanasov [1,2] developed a method for measuring the mass-center of the human body using a BED-SCALES device (Figure 1).

The bed-scales determine the section, in which the torques of the upper and down part of the body are balanced in the section O-O'. In this section, the body circumference is measured and a connection is sought between the measured body circumference and the parameters - body weight ( $\mathrm{M}, \mathrm{kg})$, body height $(\mathrm{H}, \mathrm{m})$, and body mass index (BMI, $\mathrm{kg} / \mathrm{m}^{2}$ ). Indeed, Figure 1 shows that:

$\mathrm{G}_{\text {up }} \mathrm{H}_{\text {up }}=\mathrm{G}_{\text {down }} \mathrm{H}_{\text {down }}$

$\mathrm{H}=\mathrm{H}_{\text {up }}+\mathrm{H}_{\text {down }}$

$\mathrm{G}=\mathrm{G}_{\mathrm{up}}+\mathrm{G}_{\mathrm{down}}$

Where $G, G_{\text {up }}$ and $G_{\text {down }}$ are the mass of the whole body of the upper body, and of the down body respectively. $\mathrm{H}, \mathrm{H}_{\text {up }}$ and $\mathrm{H}_{\text {down }}$ are the height of the whole body and the upper and the down part of the body, respectively. The

Correspondence to: A. T. Atanasov, Faculty of Medicine, Trakia University, Stara Zagora, Bulgaria, E-mail: atanastod@abv.bg products $\mathrm{G}_{\text {up }} \mathrm{H}_{\text {up }}$ and $\mathrm{G}_{\text {down }} \mathrm{H}_{\text {down }}$ are the torques of the upper and down body parts.

In the section $\mathrm{O}-\mathrm{O}$ ', in which the torques GupHup and Gdown Hdown are equal, the circumference of the body $\mathrm{L}$ is measured, with the help of which the center of gravity of the body is determined.

From $\mathrm{G}_{\text {up }}$ and $\mathrm{G}_{\text {down }}$ it can calculate the mass of the upper and down part of the body:

$\begin{array}{ll}\mathrm{M}_{\text {up }}=\mathrm{G}_{\mathrm{up}} / \mathrm{g} & \text { (4) } \quad \text { and } \\ \mathrm{M}_{\text {down }}=\mathrm{G}_{\mathrm{down}} / \mathrm{g} & \text { (5), where }\end{array}$

$\mathrm{g}$ is the Earth acceleration $\left(\mathrm{g}=9.81 \mathrm{~m} / \mathrm{s}^{2}\right)$.

Thus, the ratio (1) gives the form of:

$\begin{array}{llr}\mathrm{M}_{\text {up }} \mathrm{g} \mathrm{H}_{\text {up }}=\mathrm{M}_{\text {down }} \mathrm{g} \mathrm{H}_{\text {down }} & \text { (6) } \\ \mathrm{M}_{\text {up }} \mathrm{H}_{\text {up }}=\mathrm{M}_{\text {down }} \mathrm{H}_{\text {down }} & \text { or } \\ \mathrm{H}_{\text {up }} / \mathrm{H}_{\text {down }}=\mathrm{M}_{\text {down }} / \mathrm{M}_{\text {up }} & \text { (8) }\end{array}$

AIM OF THE STUDY

To investigate the ratio between the length of upper and down parts of the body in the cross section of the equal torques of the upper and the down bodily parts:

1. Measure the mass of the body $\mathrm{M}$, the height $\mathrm{H}$ of body, $\mathrm{H}_{\text {up }}$, and $\mathrm{H}_{\text {down }}$ length, $\mathrm{M}_{\text {down }}$ and 
$\mathbf{M}_{\text {up }}$ mass in the cross section of the equal torques.

2. Calculate the body mass index (BMI).
3. Calculate $\mathrm{H}_{\text {up }} / \mathrm{H}_{\text {down }}$ and $\mathrm{M}_{\text {down }} / \mathrm{M}_{\text {up }}$ ratio.

4. Investigate the statistical relationship between the measured parameters.

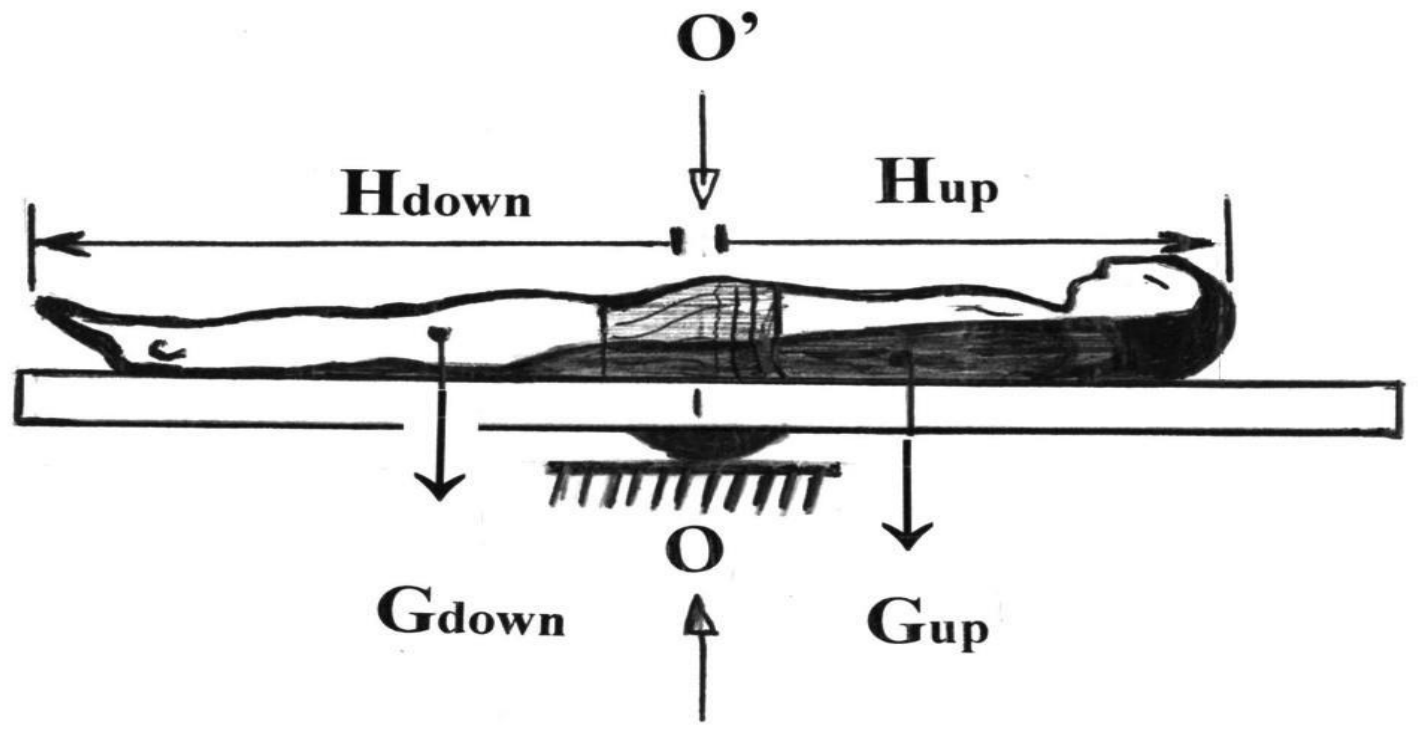

Figure 1. Bed-scales device. $\mathrm{H}_{\text {up }}$ and $\mathrm{H}_{\text {down }}$ length were measured in the cross-section OO' of the equal torques of upper and down bodily parts.

\section{MATERIALS AND METHODS}

62 people aged between 18 and 28 of both sexes were studied ( 24 men against 40 women).

The statistical program STATISTICS is used in the calculations.

The statistical significance of the found correlations was determined using Student's ttest.

\section{RESULTS}

The measured parameters - body weight $\mathrm{M}$, body height $\mathrm{H}, \mathrm{H}_{\text {up }}, \mathrm{H}_{\text {down }}$, calculated BMI and $\mathrm{H}_{\text {up }} / \mathrm{H}_{\text {down }}$ values are given in Table 1. From the ratio (8) it can see that $\mathrm{H}_{\text {up }} / \mathrm{H}_{\text {down }}$ ratio is equals to $\mathrm{M}_{\text {down }} / \mathrm{M}_{\text {up }}$ ratio, because of that the $\mathrm{M}_{\mathrm{down}} / \mathrm{M}_{\mathrm{up}}$ values are not given in Table $\mathbf{1}$.

Table 1. Body mass $M$, body height $H, B M I, H_{u p}, H_{\text {down }}$, and calculated $H_{\text {up }} / H_{\text {down }}$ ratio*.

Gender of participants are signed as $(\mathrm{m})$ man and $(w)$ woman.

\begin{tabular}{|l|l|l|l|l|l|l|}
\hline $\mathrm{N}$ & $\mathrm{M}(\mathrm{kg})$ & $\mathrm{H}(\mathrm{m})$ & $\mathrm{BMI}\left(\mathrm{kg} / \mathrm{m}^{2}\right)$ & $\mathrm{H}_{\text {up }}(\mathrm{m})$ & $\mathrm{H}_{\text {down }}(\mathrm{m})$ & $\mathrm{H}_{\text {up }} / \mathrm{H}_{\text {down }}$ \\
\hline 1 & $75(\mathrm{~m})$ & 1.87 & 21.44 & 0.82 & 1.050 & 0.78095 \\
\hline 2 & $44(\mathrm{w})$ & 1.60 & 17.1875 & 0.71 & 0.89 & 0.79775 \\
\hline 3 & $102(\mathrm{~m})$ & 1.84 & 30.1275 & 0.82 & 1.020 & 0.8039 \\
\hline 4 & $97(\mathrm{~m})$ & 1.83 & 28.9647 & 0.82 & 1.010 & 0.81188 \\
\hline 5 & $57.9(\mathrm{w})$ & 1.57 & 23.4897 & 0.70 & 0.87 & 0.80459 \\
\hline 6 & $54.4(\mathrm{w})$ & 1.55 & 22.64 & 0.71 & 0.84 & 0.84523 \\
\hline 7 & $70(\mathrm{~m})$ & 1.74 & 23.12 & 0.75 & 0.99 & 0.7575 \\
\hline 8 & $59.3(\mathrm{w})$ & 1.75 & 19.36 & 0.79 & 0.96 & 0.82251 \\
\hline 9 & $64.8(\mathrm{w})$ & 1.74 & 21.40 & 0.79 & 0.95 & 0.83157 \\
\hline 10 & $69.7(\mathrm{~m})$ & 1.64 & 25.91 & 0.70 & 0.94 & 0.7446 \\
\hline 11 & $56(\mathrm{w})$ & 1.65 & 20.57 & 0.77 & 0.88 & 0.8750 \\
\hline 12 & $64(\mathrm{~m})$ & 1.83 & 19.11 & 0.78 & 1.050 & 0.7428 \\
\hline 13 & $52.1(\mathrm{w})$ & 1.66 & 18.906 & 0.77 & 0.925 & 0.8324 \\
\hline 14 & $63.9(\mathrm{w})$ & 1.66 & 23.189 & 0.69 & 0.97 & 0.71134 \\
\hline 15 & $103(\mathrm{~m})$ & 1.7 & 35.64 & 0.73 & 0.97 & 0.7525 \\
\hline
\end{tabular}


ATANASOV A., et al.

\begin{tabular}{|c|c|c|c|c|c|c|}
\hline 16 & $66.6(\mathrm{w})$ & 1.7 & 23 & 0.76 & 0.94 & 0.8085 \\
\hline 17 & $73.5(\mathrm{~m})$ & 1.8 & 22.685 & 0.79 & 1.02 & 0.7745 \\
\hline 18 & $51(\mathrm{w})$ & 1.69 & 17.857 & 0.76 & 0.93 & 0.8172 \\
\hline 19 & $43.8(w)$ & 1.56 & 17.998 & 0.68 & 0.88 & 0.7727 \\
\hline 20 & $67.3(\mathrm{w})$ & 1.73 & 22.485 & 0.77 & 0.96 & 0.80208 \\
\hline 21 & $63(\mathrm{~m})$ & 1.78 & 19.88 & 0.80 & 0.98 & 0.8163 \\
\hline 22 & $63.5(w)$ & 1.65 & 23.32 & 0.75 & 0.90 & 0.8333 \\
\hline 23 & $86.5(\mathrm{~m})$ & 1.88 & 24.47 & 0.835 & 1.05 & 0.7952 \\
\hline 24 & $81(\mathrm{~m})$ & 1.83 & 24.187 & 0.87 & 0.97 & 0.8969 \\
\hline 25 & $82(\mathrm{~m})$ & 1.77 & 26.17 & 0.79 & 0.97 & 0.8144 \\
\hline 26 & $95(\mathrm{~m})$ & 1.9 & 26.315 & 0.83 & 1.08 & 0.7685 \\
\hline 27 & $81(\mathrm{~m})$ & 1.78 & 25.564 & 0.78 & 1.00 & 0.78 \\
\hline 28 & $93(\mathrm{~m})$ & 1.75 & 30.367 & 0.71 & 1.04 & 0.6893 \\
\hline 29 & $86(\mathrm{~m})$ & 1.85 & 25.128 & 0.81 & 1.05 & 0.7714 \\
\hline 30 & 73(m) & 1.83 & 21.798 & 0.80 & 1.03 & 0.7767 \\
\hline 31 & $55(w)$ & 1.73 & 18.377 & 0.79 & 0.94 & 0.8404 \\
\hline 32 & $76(\mathrm{~m})$ & 1.88 & 21.50 & 0.84 & 1.04 & 0.8077 \\
\hline 33 & $90(\mathrm{~m})$ & 1.88 & 25.46 & 0.82 & 1.05 & 0.78095 \\
\hline 34 & $50.7(\mathrm{w})$ & 1.59 & 20.05 & 0.70 & 0.89 & 0.7865 \\
\hline 35 & $74(w)$ & 1.6 & 28.906 & 0.71 & 0.88 & 0.8068 \\
\hline 36 & $58(w)$ & 1.55 & 24.14 & 0.70 & 0.86 & 0.81395 \\
\hline 37 & $88(\mathrm{~m})$ & 1.74 & 29.065 & 0.76 & 0.98 & 0.7755 \\
\hline 38 & $60(\mathrm{w})$ & 1.64 & 22.30 & 0.69 & 0.96 & 0.71875 \\
\hline 39 & $110(\mathrm{~m})$ & 1.81 & 33.57 & 0.81 & 1.0 & 0.81 \\
\hline 40 & $56(w)$ & 1.54 & 23.61 & 0.68 & 0.87 & 0.7816 \\
\hline 41 & $95(\mathrm{~m})$ & 1.79 & 29.65 & 0.75 & 1.04 & 0.7211 \\
\hline 42 & $54(w)$ & 1.70 & 18.685 & 0.74 & 0.96 & 0.7708 \\
\hline 43 & $54(w)$ & 1.7 & 18.685 & 0.74 & 0.96 & 0.7708 \\
\hline 44 & $54(w)$ & 1.59 & 21.36 & 0.70 & 0.90 & 0.7777 \\
\hline 45 & $55(\mathrm{w})$ & 1.60 & 21.484 & 0.70 & 0.90 & 0.7777 \\
\hline 46 & $59.5(w)$ & 1.63 & 22.394 & 0.73 & 0.90 & 0.81111 \\
\hline 47 & $104(\mathrm{~m})$ & 1.8 & 32.1 & 0.74 & 1.05 & 0.7047 \\
\hline 48 & $63(w)$ & 1.68 & 22.32 & 0.77 & 0.92 & 0.83695 \\
\hline 49 & $75.5(\mathrm{~m})$ & 1.84 & 22.287 & 0.77 & 1.06 & 0.7264 \\
\hline 50 & $55(\mathrm{w})$ & 1.72 & 18.591 & 0.76 & 0.96 & 0.7917 \\
\hline 51 & $67(w)$ & 1.70 & 23.18 & 0.76 & 0.94 & 0.8085 \\
\hline 52 & $57(w)$ & 1.65 & 20.936 & 0.73 & 0.93 & 0.7849 \\
\hline 53 & $83(w)$ & 1.60 & 32.422 & 0.68 & 0.91 & 0.74725 \\
\hline 54 & $52(\mathrm{w})$ & 1.54 & 21.93 & 0.71 & 0.83 & 0.8554 \\
\hline 55 & $47(w)$ & 1.64 & 17.475 & 0.77 & 0.87 & 0.885 \\
\hline 56 & $54(w)$ & 1.63 & 20.32 & 0.72 & 0.92 & 0.7826 \\
\hline 57 & $90(w)$ & 1.62 & 34.293 & 0.73 & 0.89 & 0.8202 \\
\hline 58 & $60(w)$ & 1.5 & 26.66 & 0.66 & 0.85 & 0.7764 \\
\hline 59 & $59(\mathrm{w})$ & 1.65 & 21.671 & 0.72 & 0.94 & 0.7595 \\
\hline 60 & $62(\mathrm{w})$ & 1.63 & 23.335 & 0.72 & 0.91 & 0.7912 \\
\hline 61 & $51(w)$ & 1.54 & 21.5 & 0.68 & 0.87 & 0.7816 \\
\hline 62 & $47(w)$ & 1.58 & 18.827 & 0.70 & 0.87 & 0.8046 \\
\hline
\end{tabular}


A parametric linear regression analysis of the statistical relationship between the body parameters $(\mathrm{a}, \mathrm{b}, \mathrm{c})$ was performed:

a. $\left(\mathrm{H}_{\text {up }} / \mathrm{H}_{\text {down }}\right)$ ratio and body height $(\mathrm{H})$ of the subjects - Figure 2. b. $\left(\mathrm{H}_{\text {up }} / \mathrm{H}_{\text {down }}\right)$ ratio and body mass $(\mathrm{M})$ of the subjects - Figure 3.

c. $\left(\mathrm{H}_{\text {up }} / \mathrm{H}_{\text {down }}\right)$ ratio and body mass index (BMI) of the subjects -Figure 4.

Table 2 presents the studied dependencies and their correlation coefficients.

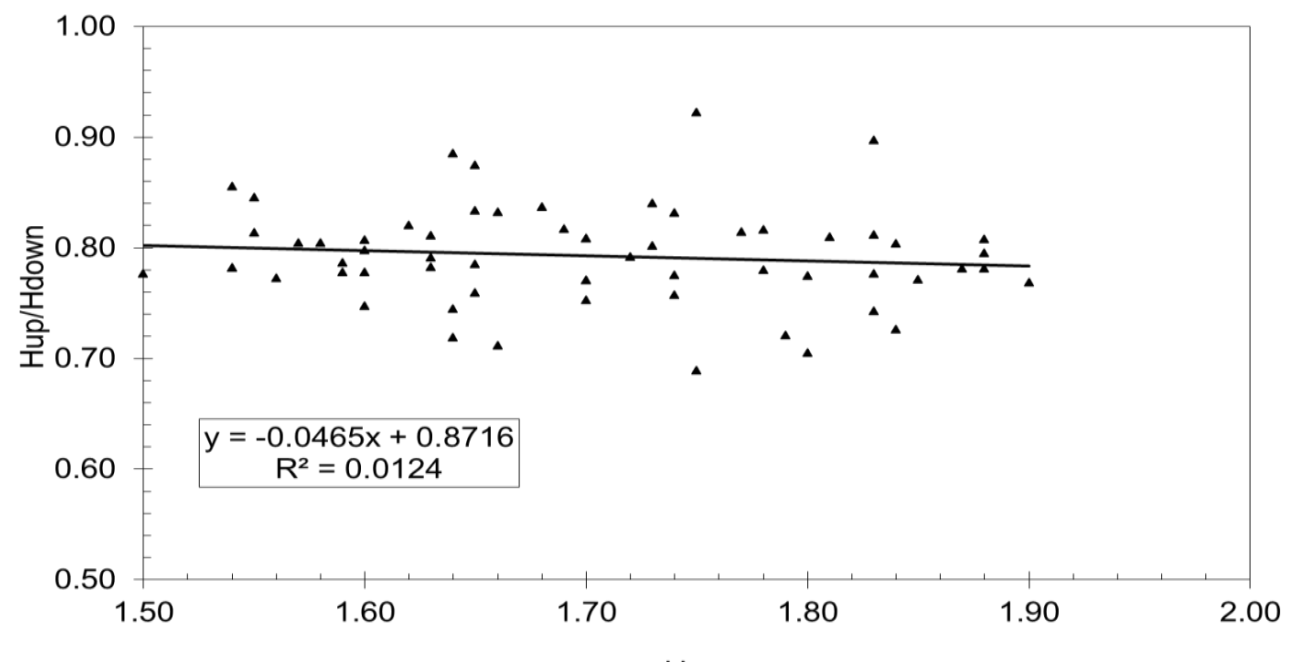

$\mathrm{H}, \mathrm{m}$

Figure 2. Relationship between $\mathrm{H}_{\text {up }} / \mathrm{H}_{\text {down }}$ and body height $\mathrm{H}$.

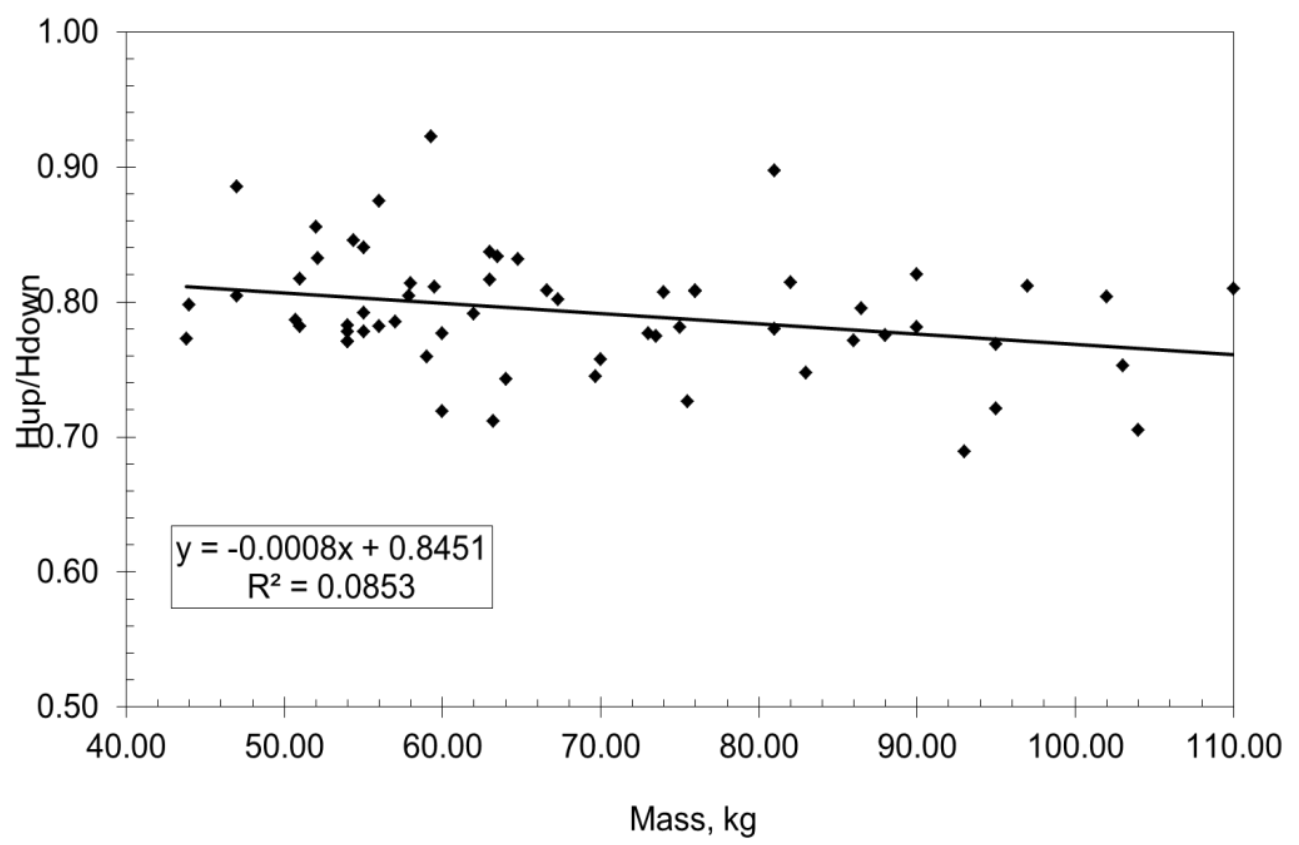

Figure 3. Relationship between $H_{\text {up }} / H_{\text {down }}$ and body mass $M$.

Table 2. The studied bodily dependencies and their correlation coefficients

\begin{tabular}{|l|l|lc|}
\hline Measured values & \multicolumn{1}{|c|}{ Statistical relationship } & $\begin{array}{l}\text { Correlation } \\
\text { coefficients }\end{array}$ & $\begin{array}{c}\text { (Statistical - } \\
\text { significance })\end{array}$ \\
\hline 1$) . \mathrm{H}_{\text {up }} / \mathrm{H}_{\text {down }}-\mathrm{H}$ & $\mathrm{H}_{\mathrm{up}} / \mathrm{H}_{\text {down }}=-0.0465 \mathrm{H}+0.8716$ & $\mathrm{R}=-0.11$ & $(\mathrm{p}>0.05)$ \\
\hline 2$) . \mathrm{H}_{\text {up }} / \mathrm{H}_{\text {down }}-\mathrm{M}$ & $\mathrm{H}_{\text {up }} / \mathrm{H}_{\text {down }}=-0.0008 \mathrm{M}+0.8451$ & $\mathrm{R}=-0.29$ & $(\mathrm{p}<0.05)$ \\
\hline 3$) . \mathrm{H}_{\text {up }} / \mathrm{H}_{\text {down }}-\mathrm{BMI}$ & $\mathrm{H}_{\mathrm{up}} / \mathrm{H}_{\text {down }}=-0.0031 \mathrm{BMI}+0.8666$ & $\mathrm{R}=-0.31$ & $(\mathrm{p}<0.05)$ \\
\hline
\end{tabular}


From experimental data on Table $\mathbf{2}$ and Figure 2 it can see that the ratio $\mathrm{H}_{\text {up }} / \mathrm{H}_{\text {down }}$ in the cross section of the equal torques of the upper and lower bodily parts don't depend from body height $\mathrm{H}$. The correlation coefficient between $\mathrm{H}_{\text {up }} / \mathrm{H}_{\text {down }}$ and $\mathrm{H}$ (see Eq. 1 ) is very low $\quad(\mathrm{R}=-$ 0.11) and the connection between two quantities do not have statistical significance ( $>0.05)$.

The calculated $\mathrm{H}_{\text {up }} / \mathrm{H}_{\text {down }}$ ratio of 62 persons fall in the range of $0.75-0.832$ with mean $( \pm \mathrm{SD})$ equals to $0.791( \pm 0.041)$. Independently to the body height, the body mass and the body-mass index this, this ratio remains constantly: $\mathrm{H}_{\text {up }} / \mathrm{H}_{\text {down }}=0.791 \mathrm{H}$.
Because of $\mathrm{H}_{\text {up }} / \mathrm{H}_{\text {down }}=\mathrm{M}_{\text {down }} / \mathrm{M}_{\text {up }}$, the ratio between the down and the upper body mass in the cross section of the equal torques is equals to: $\mathrm{M}_{\text {down }} / \mathrm{M}_{\text {up }}=0.791 \mathrm{H}$.

From experimental data on Table 2 and Figure 3, and Figure 4 is observed that the relationship $\mathrm{H}_{\text {up }} / \mathrm{H}_{\text {down }}$ depends slightly from the body mass $\mathrm{M}$ (Eq.2) and the body mass index BMI (Eq.3). In the two cases the correlation coefficients $\mathrm{R}=-0.29$ and $\mathrm{R}=$ 0.31 are low, but the connection between $\mathrm{H}_{\text {up }} / \mathrm{H}_{\text {down }}$ and $\mathrm{M}$, and BMI have a statistically significance $(\mathrm{p}<0.05)$.

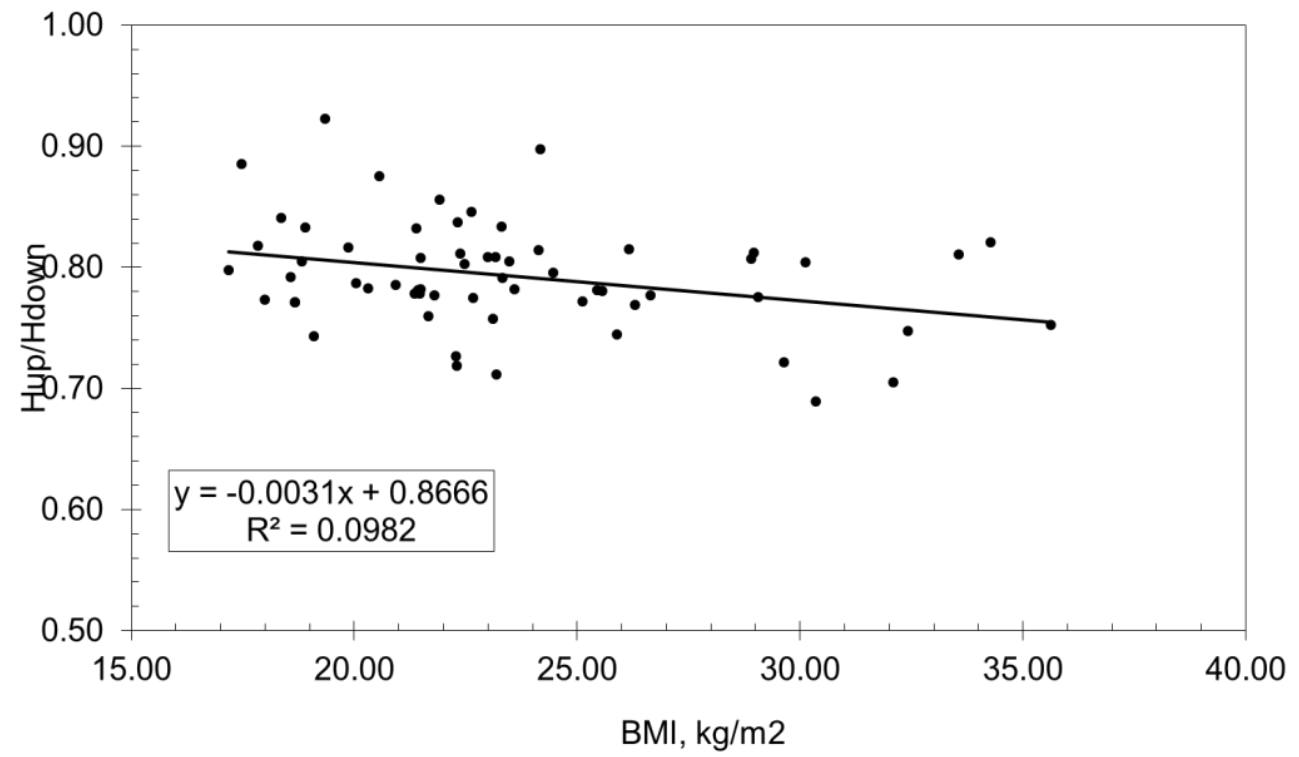

Figure 4. Relationship between $\mathrm{H}_{\mathrm{up}} / \mathrm{H}_{\text {down }}$ and BMI.

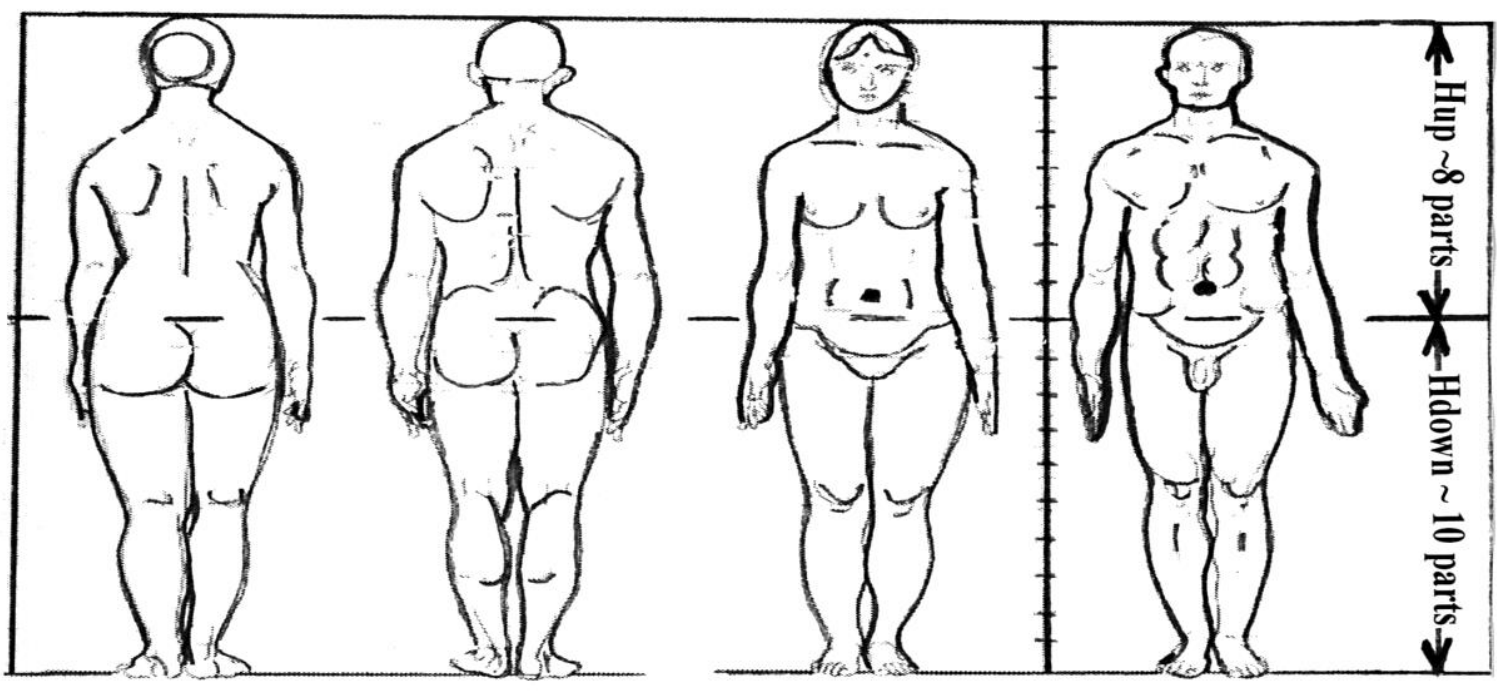

Figure 5. The approximate location of the cross section of the equal torques of the upper and lower part of the human body: Hup / Hdown 8/10. 


\section{DISCUSSION}

The ratio $\mathrm{H}_{\text {up }} / \mathrm{H}_{\text {down }}$ remains constantly, independently to the gender, the body height, the body mass and the body-mass index: $\mathrm{H}_{\text {up }} / \mathrm{H}_{\text {down }}=0.791 \mathrm{H}\left(/\right.$ i.e. $\left.\mathrm{H}_{\text {up }} / \mathrm{H}_{\text {down }} \sim 0.8 \mathrm{H}\right)$.

Because of $\mathrm{H}_{\text {up }} / \mathrm{H}_{\text {down }}=\mathrm{M}_{\text {down }} / \mathrm{M}_{\text {up }}$, the ratio between the down and the upper body parts of the mass in the cross section of the equal torques is

equals to: $\mathrm{M}_{\text {down }} / \mathrm{M}_{\text {up }}=0.791 \mathrm{H}$ (i.e. $\mathrm{M}_{\text {down }} / \mathrm{M}_{\text {up }}$ $\sim 0.8 \mathrm{H}$ ).

On Figure 5 is shown the approximate location of the cross section of the equal torques of the body.

The find relationships can be used to solve various scientific problems such as abdominal obesity, spinal deformities and others [3-6].

\section{CONCLUSSION}

The ratio between the length of $\mathrm{H}_{\mathrm{up}}$ and $\mathrm{H}_{\mathrm{down}}$ part of the body in the cross section of the equal torques of upper and lower bodily parts appears nearly an anatomical constant. This ratio can be presented as $\mathrm{H}_{\text {up }} / \mathrm{H}_{\text {down }} \sim 8 / 10$.

\section{REFERENCES}

1. Atanasov, A.T., Method for determining the human body-mass center. Trakia Journal of Sciences, 17(2):1-3, 2020.

\section{ATANASOV A., et al.}

2. Atanasov, A.T., N. Pirovski and D.T. Valev. Research on the body-mass index of the body and the body circumference in the current section of the equal rotation moments of the upper and lower part of the body. Trakia Journal of Sciences, 18 (Suppl. 1):80-85, 2020.

3. Atanasov, A., Todorova, M., Valev, D. and R. Todorova, Alometric relationships between the body-mass index, mass to surface ratio and the length of pregnancy in some mammals. Trakia Journal of Sciences, 12, 70-73, 2014.

4. Paskaleva, R. and of the Muskov quadragle for the evaluation of the muscle disorders in children and adults. AIP Conference Proceedings, 2075, 170029, 2019. https://doi.org/10.1063/1.5091394.

5. AT Atanasov, DT Valev, R Todorova. Allometric relationships between the body parameters of mammals (from $S$. Araneus to M. Musculus). General equations. Bulgarian Journal of Veterinary Medicine, 22, Suppl.1, 4-9, 2019.

6. AT Atanasov, DT Valev, R Todorova. Allometric relationships between the body parameters of mammals (from $S$. Araneus to M. Musculus). Similarity between body mass index and mass to surface ratio. Bulgarian Journal of Veterinary Medicine, 22, Suppl.1, 10-14, 2019. 